\title{
Commentary: Integrating Social Aspects into Biomedicine
}

\author{
Sara Johnsdotter and Håkan Eriksson
}

Faculty of Health and Society, Malmö University, SE-205 06 Malmö, Sweden

Modern biomedicine excels in discoveries in areas such as identification of pathogens and biochemical pathways, and the unveiling of genetic information. This remarkable development had its starting point back in the $19^{\text {th }}$ century with the discovery of how microorganisms were related to disease. Until this point in time physicians primarily had to rely on patients' subjective illness experiences and social behavior in deciding diagnosis and treatment [1].

A characteristic of modern biomedical science is the separation of body and mind, while it is simultaneously conceded that they cannot really be separated. The notion of a division between the two is a basic train of thought that goes far back in time, but is primarily ascribed to René Descartes (1596-1637). In his thesis Treatise on Man, Descartes described the body as material and compared it to a machine, while the mind (or soul) was nonmaterial and immortal. He contended that the two could almost never meet [2] and thus he is the origin of the term Cartesian dualism, which refers to such attempts to separate body and mind. This separation - in medicine, basically one where psychiatry takes care of the mind and the rest of the medical specialties focus on the body alone - has been one of the hallmarks of modern biomedicine.

"Reductionism now, for the first time, loomed large in medicine's agenda", says historian of medicine Roy Porter [3], "explaining the whole in terms of its parts, the complex in the terms of the simple, the biological in terms of the physical or chemical."

Scientific achievements in the $18^{\text {th }}, 19^{\text {th }}$ and $20^{\text {th }}$ centuries corroborated such mechanistic a view of the human body. Step by step, especially during the 1800 s, medical science and practice moved away from the medical system inherited from the ancient Greeks, where - even though their treatments were not evidence-based and often detrimental to health - the patient rather than the disease had been in focus [3].

*Address correspondence to this author at the Faculty of Health and Society, Malmö University, SE-205 06 Malmö, Sweden; Tel: +46406657925;

Fax:+46406658100; E-mail: hakan.eriksson@mah.se
The invention of man-made immunization in the late $18^{\text {th }}$ century and the germ theory in the $19^{\text {th }}$ century confirmed that disease was related to external factors and paved the way for a medical practice founded in natural sciences, especially biochemistry [2].

When illness and disease moved into the laboratories, the role of social and cultural factors for bodily processes was almost totally discarded. While many physicians continued to cultivate the doctorpatient relationship at the bedside in hospitals or in clinics, the medical science flourished with new discoveries regarding microorganisms, cells, genes, hormones, enzymes and other biological and biochemical entities [2, 4], which seemed to exist and thrive beyond social and cultural realities.

During the last decades it has become increasingly clear that an all-encompassing understanding of physiology and pathology requires that social and cultural factors be taken into consideration. The high placebo effect obtained during clinical trials is evidence of this. The pathways of the placebo effect are slowly being uncovered and this research testifies to the importance of factors not traditionally pertaining to biochemistry $[5,6]$.

The focus in placebo studies is now shifting, from whether or not a placebo effect occurs during a clinical study to investigations into how the placebo effect works [7]. Dose-response dependent effects of placebo have been shown [8] and these kinds of studies have revealed that we hitherto have lacked an awareness and deeper understanding of the biochemical machinery that controls and guides the human biology. Today's studies, aiming at uncovering the biological mechanisms behind the placebo effects, gain and disclose new insights about vital biochemical processes. These studies will advance our clinical medical chemistry in the future.

Without exaggerating, it can well be assumed that the "therapeutic rituals" in medical clinics induce a lot of chemistry in the human brain and several reports have shown changes in the biochemistry of the endocrine 
and neural system upon placebo treatment [9, 10]. However, not all patients respond and show placebo effects and this may well depend on individual genetic susceptibilities. Genes associated with placebo effects have been identified [11] and it still is a conundrum why genes favouring placebo effects are sustained in the human genome.

Another intriguing example is genes associated with depression and the question of why these were not removed from the human genome during human evolution. Several of these genes have been identified to be associated with the innate immune inflammatory response [12], which may explain the benefit of these genes and their prevalence in the human genome. These genes associated with depression can be viewed upon as genes initiating or affecting an inflammatory response, and downstream of the induced physiological process, i.e., the inflammation, events will induce depression. However, the physiological response downstream of the genes can also be understood in the reversed orientation. In this scenario the genes affect the central nervous system (CNS) and induce depression, which further on affects the induction and the maintenance of an inflammatory response. The immune system is one of the body's strongest and most efficient defense systems and the possibility of CNS as an inducer or activator of an immune response opens for new opportunities and possibilities of explaining observed placebo effects. In this case, the genes are not decoded due to the presence of pathogen but rather due to social, cultural or other factors not traditionally belonging to the field of biochemistry and medicine.

The examples above show the potential of studies investigating the interface of biochemical activity and social and cultural contexts, and how these can advance our understanding of the biochemical and physiological processes of the human entity. Future research needs to be multidisciplinary in order to reveal and identify areas of biomedicine so far missed. The German physician Rudolph Virchow (1821-1902), specialized in cell biology among other things and often referred to as 'the father of modern pathology', once claimed "medicine is social science in its very bone and marrow" [13]. This view seems to go through a renaissance today; more and more physicians and biomedical scholars call for research approaches that are wider in scope when human health, illness and disease are investigated. As remarked by American physician Thomas E Kottke,
The tools of $21^{\text {st }}$ century medicine include anatomy, physiology, pharmacology, genomics, proteomics, and the related sciences, but it is only when social science is added to the tool box that medicine gains the ability to understand and respond to the wants and needs of individual patients, social networks, and whole communities [13].

Aware of this, Harvard Medical School in collaboration with a wide range of academic institutions has started a research program on the placebo phenomenon - an enterprise where clinical researchers, neuroscientists, geneticists, and molecular biologists work side by side with social scientists and researchers from the humanities and bioethics. The research group declares in their program description that attitudes to the placebo effect have transformed: from being seen as a nuisance variable in clinical trials, placebo effects today are described as "the key to understanding the healing that arises from medical ritual, the context of treatment, the patientprovider relationship and the power of imagination, trust and hope" [14]. In other words, physiological and biochemical reactions are embedded in and impacted by social and cultural contexts.

The body cannot be reduced to a machine, and the body and mind cannot be investigated as separate entities. Collaboration between biomedical researchers and scholars from the social sciences and the humanities has a potential to capture more complex relations in the field of health and disease, and, in the end, make scientific contributions that better mirror the intricate conditions of human life.

\section{REFERENCES}

[1] Radley A. Making Sense of Illness: The Social Psychology of Health and Disease. London: Sage 1994.

[2] Porter R. The Greatest Benefit to Mankind: A Medical History of Humanity from Antiquity to the Present. London: Harper Collins 1997.

[3] Porter R. Cambridge Illustrated History of Medicine Cambridge University Press 1996.

[4] Pickstone JV. Ways of Knowing: A New History of Science, Technology and Medicine. Manchester: Manchester University Press 2000.

[5] Finniss DG, Kaptchuk TJ, Miller F, Benedetti F. Biological, clinical, and ethical advances of placebo effects. Lancet 2010; 375: 686-695. http://dx.doi.org/10.1016/S0140-6736(09)61706-2

[6] Enck $P$, Bingel U, Schedlowski M, Rief W. The placebo response in medicine: minimize, maximize or personalize? Nat Rev Drug Discov 2013; 12: 191-204.

http://dx.doi.org/10.1038/nrd3923 
[7] Feinberg C. The placebo phenomenon. Harvard Magazine, Dec 9, 2012; 36-39.

[8] Nakamura $\mathrm{Y}$, Donaldson GW, Kuhn R, Bradshaw DH, Jacobson RC, Chapman CR. Investigating dose-dependent effects of placebo analgesia: A psychophysiological approach. Pain 2012; 153: 227-37.

http://dx.doi.org/10.1016/j.pain.2011.10.024

[9] Benedetti F. Placebo effects: Understanding the mechanisms in health and disease. Oxford University Press 2012.

[10] Meissner K. The placebo effect and the autonomic nervous system: evidence for an intimate relationship. Philosophical Transaction of the Royal Society B 2011; 366: 1808-817

[11] Hall KT, Lembo AJ, Kirsch I, Ziogas DC, Douaiher J, Jensen KB, Conboy LA, Kelley JM, Kokkotou E, Kaptchuk TJ.
Catechol-O-methyltransferase val158met polymorphism predicts placebo effect in irritable bowel syndrome. PLOS ONE 2012; 7(10): e48135.

[12] Raison $\mathrm{CL}$, Miller $\mathrm{AH}$. The evolutionary significance of depression in pathogen host defense (PATHOS-D). Molecular Psychiatry 2013; 18: 15-37.

[13] Kottke TE. Medicine is a social science in its very bone and marrow. Mayo Clin Proc 2011; 86(10): 930-32.

http://dx.doi.org/10.4065/mcp.2011.0444

[14] PiPS 2013. Placebo Studies and the Therapeutic Encounter (PiPS). http://programinplacebostudies.org/ (accessed May 6, 2013).

Received on 10-06-2013

Published on 30-06-2013

DOI: http://dx.doi.org/10.12970/2308-8044.2013.01.01.6

(C) 2013 Johnsdotter and Eriksson; Licensee Synergy Publishers.

This is an open access article licensed under the terms of the Creative Commons Attribution Non-Commercial License (http://creativecommons.org/licenses/by-nc/3.0/) which permits unrestricted, non-commercial use, distribution and reproduction in any medium, provided the work is properly cited. 